\title{
TOKSISITAS BEBERAPA EKSTRAK RIMPANG CABANG TEMULAWAK (Curcuma xanthorrhiza Roxb.) PADA LARVA UDANG (Artemia salina Leach)
}

\author{
Prasetyorini ${ }^{1}$, Ike Yulia Wiendarlina ${ }^{2}$, Anisa Bela Peron ${ }^{2}$ \\ ${ }^{1)}$ Program Studi Biologi, FMIPA, Universitas Pakuan \\ ${ }^{2)}$ Program Studi Farmasi, FMIPA, Universitas Pakuan \\ Email : prasetyorini67@yahoo.co.id
}

\begin{abstract}
ABSTRAK
Pengujian toksisitas beberapa ekstrak rimpang temulawak hasil ekstraksi dengan metode yang berbeda telah dilakukan terhadap larva udang Artemia salina dengan menggunakan Brine Shrimp Lethality Test (BSLT). Ekstraksi dilakukan dengan metode maserasi, sokletasi dan refluks. Pelarut yang digunakan untuk ekstraksi adalah etanol $96 \%$. Toksisitas diukur dengan menghitung jumlah larva udang yang mati, kemudian nilai $\mathrm{LC}_{50}$ untuk setiap ekstrak ditentukan dengan menggunakan Probit Analisis Method. Hasil penelitian menunjukkan bahwa nilai $\mathrm{LC}_{50}$ ekstrak yang diperoleh dengan metode maserasi, soxhlet dan refluks berturut-turut adalah $14.87 \mathrm{ppm}, 19.13 \mathrm{ppm}$ dan $35.92 \mathrm{ppm}$. Ekstrak rimpang temulawak dengan metode maserasi merupakan ekstrak teraktif. Hasil penapisan fitokimia menunjukkan bahwa dalam ekstrak hasil maserasi tersebut dapat diidentifikasi adanya senyawa golongan alkaloid, flavonoid, steroid, kuinon dan triterpenoid.
\end{abstract}

\section{Kata kunci : Curcuma xanthorrhiza Roxb., toksisitas, Artemia salina Leach}

\section{PENDAHULUAN}

Tumor adalah suatu penyakit sel dengan ciri gangguan atau kegagalan mekanisme pengatur multiplikasi dan fungsi homeostatis lainnya yang terjadi pada organisme multiseluler. Jenis tumor ada 2 macam, yaitu tumor jinak dan tumor ganas. Tumor jinak mempunyai sifat tidak banyak mengganggu organ yang terkena, dan pertumbuhannya sangat lambat atau bahkan tidak menyebar. Tumor ganas mempunyai sifat yang sangat berbeda, karena mempunyai pertumbuhan yang sangat cepat yang menyebabkan gangguan pada fungsi organ yang terkena, selain itu sifat tumor ganas yang sangat ditakuti adalah daya sebarnya yang sangat cepat. Tumor ganas ini dikenal dengan sebutan kanker, dan penyebab kanker disebut karsinogen (Sidik et al., 1992).

Tahap-tahap penting pembentukan sel kanker adalah inisiasi dengan terjadinya perubahan DNA, promosi yang meliputi perkembangbiakan sel dan perubahan menjadi premalignant, serta tahap progesi dan invasi (penyusupan ke jaringan sekitar) dan metastesis yaitu penyebaran melalui pembuluh darah dan pembuluh getah bening (Schunack et al., 1990).

Karena banyaknya faktor endogen dan eksogen yang berperan pada timbulnya tumor atau kanker, maka pencegahan ataupun pengobatannya menjadi sesuatu yang cukup kompleks. Beberapa obat yang dinyatakan sebagai antikanker sebenarnya merupakan analog sintetik dari obat-obat yang sudah dikenal efektif. Sebagian diantaranya merupakan bahan alam yang diisolasi dari mikroorganisme atau tumbuhan, serta sebagian lain mewakili upaya dalam rancangan obat yang rasional berdasarkan kemampuannya untuk menghambat kerja enzim atau komponen lain yang essensial untuk pertumbuhan sel tumor. Salah satu bahan alam yang pernah diteliti aktivitasnya untuk aktivitas antitumor adalah temulawak (WHO, 1999).

Temulawak (Curcuma xanthorrhiza Roxb.) adalah salah satu tanaman obat yang sering digunakan oleh masyarakat 
Indonesia sebagai obat tradisional, tanaman ini termasuk ke dalam famili Zingiberacae. Temulawak adalah tanaman monokotil yang tidak memiliki akar tunggang, akar yang dimiliki berupa rimpang yang terdiri dari rimpang utama (induk) dan rimpang samping (cabang). Rimpang induk atau rimpang utama berbentuk jorong atau gelendong, sedangkan rimpang samping atau rimpang cabang berupa akar yang menggembung pada ujungnya membentuk umbi. Rimpang samping atau cabang yang dihasilkan setiap kali pemanenan jumlahnya hampir sama dengan rimpang utama, tetapi rimpang cabang ini selalu dibuang karena dianggap tidak mempunyai khasiat obat, untuk itu perlu dilakukan penelitian untuk mengetahui kandungan zat berkhasiat dan potensi sebagai tanaman obat. Rimpang temulawak diketahui memiliki banyak manfaat diantaranya sebagai antihepatitis, antihiperlipidemia, antiinflamasi, antitumor, antioksidan, antikarsinogenik, antimikroba, antivitral dan detoksifikasi (WHO, 1999)

Penelitian terdahulu terhadap rimpang temulawank (Curcuma xanthorriza Roxb.), diketahui bahwa rimpang temulawak merupakan salah satu bagian tanaman yang dimanfaatkan dalam mencegah dan mengobati berbagai penyakit. Rimpang temulawak mengandung dua komponen utama yaitu 1,6-2,2\% kurkuminoid dan 1,48-1,63\% minyak atsiri, selain itu rimpang temulawak segar juga mengandung selulosa, pati, protein, mineral (Depkes, 1979). Pemanfaatan bahan tanaman sebagai bahan obat sangat ditentukan oleh kandungan zat aktif yang dikandung dalam bahan tanaman tersebut. Mendapatkan bahan aktif dari dalam tanaman juga sangat ditentukan oleh bagaimana cara atau metode mengekstraksinya. Disamping metode ekstraksi bahan aktif tersebut juga ditentukan oleh pelarut yang digunakan.

Metode Brine Shrimp Lethality Test (BSLT) adalah metode menguji aktivitas suatu senyawa menggunakan hewan uji berupa larva udang Artemia salina Leach. Metode ini merupakan salah satu metode yang banyak digunakan dalam memandu pencarian senyawa anti kanker yang berasal dari tumbuhan. Metoda ini telah digunakan sejak 1956 untuk berbagai pengamatan bioaktivitas antara lain untuk mengetahui residu pestisida, anestetik lokal, senyawa turunan morfin, mikotoksin, karsinogenesitas suatu senyawa (Meyer, 1982). Metode ini merupakan bioassay yang cepat, murah, dapat dipercaya dan hasil yang diperoleh sering dihubungkan dengan aktivitas sitotoksik yang merupakan syarat utama obat-obat antitumor. Sementara, hasil ekstraksi dengan metode yang berbeda juga akan menghasilkan ekstrak yang berbeda. Berdasarkan alasan yang telah diuraikan, maka perlu dilakukan penelitian tentang pengaruh metode ekstraksi rimpang cabang temulawak terhadap toksisitas larva $A$. salina dengan uji BSLT. Penelitian ini juga untuk mengetahui apakah rimpang cabang temulawak mempunyai bioaktivitas seperti rimpang induk. Tujuan penelitian ini adalah untuk mengetahui adanya pengaruh metode ektraksi rimpang cabang temulawak (Curcuma xanthorriza Roxb.) terhadap toksisitas larva udang (Artemia salina Leach.).

\section{METODE PENELITIAN}

Penelitian ini dilakukan pada bulan Desember 2006 sampai Februari 2007 di Laboratorium Farmasi Fakultas Matematika dan Ilmu Pengetahuan Alam Universitas Pakuan dan Laboratorium Uji Biofarmaka, Bogor.

\section{Bahan}

Rimpang cabang temulawak yang didapat dari Kebun Percobaan Balai Penelitian Tanaman Industri di Sukamulya Sukabumi, telur Artemia salina Leach, etanol $96 \%$, aquadest, air laut, Tween 80, pereaksi Dragendorf, Mayer, Wagner, $\mathrm{NH}_{3}$, $\mathrm{CHCl}_{3}, \mathrm{H}_{2} \mathrm{SO}_{4} 2 \mathrm{M}$, serbuk $\mathrm{Mg}, \mathrm{HCl}$ pekat, amil alkohol, $\mathrm{FeCl}_{3} 10 \%$, dietil eter, $\mathrm{H}_{2} \mathrm{SO}_{4}$ 
pekat, $\mathrm{CH}_{3} \mathrm{COOH}$ anhidrat, metanol, $\mathrm{NaOH} 10 \%$, toluen, etil Asetat, asam format.

Alat

Rotary evaporator, bejana kromatografi, lempeng tetes, plat kromatografi, silica gel $\mathrm{GF}_{254}$, cawan penguap, neraca analitik, eksikator.

\section{Cara Kerja}

Penelitian dilakukan dalam dua tahap. Tahap pertama adalah analisis pendahuluan yang meliputi pengujian kadar air, kadar abu, dan uji fitokimia terhadap serbuk simplisia kering rimpang cabang temulawak. Tahap kedua adalah ekstraksi, metode ekstraksi yang digunakan untuk pengambilan ekstrak adalah tiga metode yaitu maserasi, sokletasi dan refluks. Metode ekstraksi yang berbeda dilakukan untuk melihat pengaruh suhu pada keaktifan tiap ekstrak terhadap toksisitas larva udang $A$. salina dan perolehan rendemen. Pelarut yang digunakan untuk ekstraksi rimpang cabang temulawak adalah etanol 96\%. Penggunaan etanol dimaksudkan agar semua senyawa kimia baik yang kurang polar, semi polar sampai polar dapat terekstraksi semaksimal mungkin. Umumnya etanol dapat mengekstraksi senyawa alkaloid, sterol, saponin, flavonoid, antrakuinon dan glikosida (Harborne, 1987).Selanjutnya menguji senyawa yang terekstrak terhadap larva udang $A$. salina yang telah berumur 48 jam. Ekstrak yang menunjukkan toksisitas paling tinggi kemudian dilakukan uji KLT dan fitokimia.

\section{Uji Fitokimia}

Uji fitokimia didasarkan pada identifikasi warna dan endapan yang terbentuk, meliputi alkaloid, flavonoid, tanin, saponin, triterpenoid/steroid dan kuinon. Uji Alkaloid dilakukan dengan menimbang 1 gram sampel ditambahkan beberapa tetes $\mathrm{NH}_{3}$ lalu dihaluskan dan tambahkan $5 \mathrm{~mL}$ kloroform kemudian disaring, filtrat ditambahkan beberapa tetes asam sulfat $2 \mathrm{M}$, lalu dikocok sehingga terbentuk dua lapisan. Lapisan asam dipisahkan, kemudian larutan dibagi ke dalam 3 tabung reaksi. Ke dalam masingmasing tabung ditambahkan pereaksi Dragendorf, Mayer dan Wagner. Uji positif ditunjukkan dengan terbentuknya endapan warna merah jingga pada pereaksi Dragendorf, endapan putih pada pereaksi Mayer dan endapan coklat pada pereaksi Wagner.

Uji steroid-triterpenoid dilakuan dengan menimbang 1 gram sampel ditambah etanol panas sambil diaduk kemudian disaring, selanjutnya filtrat dipanaskan hingga kering, kemudian tambahkan 1 tetes $\mathrm{H}_{2} \mathrm{SO} 4$ pekat dan 1 tetes $\mathrm{CH}_{3} \mathrm{COOH}$ anhidrat. Bila dihasilkan warna hijau atau biru menandakan adanya steroid sedangkan warna merah atau ungu menandakan sampel positif mengandung triterpenoid.

Uji flavonoid, saponin, sanin dilakukan dengan menimbang 5 gram serbuk simplisia masukkan dalam gelas piala tambahkan $100 \mathrm{~mL}$ aquadest dan didihkan selama 5 menit, kemudian disaring dan filtratnya digunakan untuk pengujian. Sebanyak $10 \mathrm{~mL}$ filtrat ditambahkan serbuk magnesium, 0,2 mL $\mathrm{HCl}$ pekat lalu ditambahkan amil alkohol. Campuran dikocok dan biarkan memisah. Senyawa flavonoid ditandai dengan terbentuk warna merah, kuning, jingga pada lapisan amil alkohol.

Uji saponin dilakukan dengan pengocokan $10 \mathrm{~mL}$ filtrat dalam tabung reaksi tertutup selama 10 detik kemudian dibiarkan selama 10 menit. Adanya saponin ditandai dengan terbentuknya busa yang stabil. Uji tanin dilakukan dengan menambahkan kedalam $10 \mathrm{~mL}$ filtrat beberapa tetes $\mathrm{FeCl}_{3} 1 \%$. Identifikasi tanin ditunjukkan dengan terbentuknya warna biru atau hijau kehitaman. Uji kuinon dilakukan dengan menimbang 1 gram sampel ditambahkan metanol kemudian dipanaskan dan disaring, selanjutnya filtrat 
diuji dengan menambahkan 3 tetes $\mathrm{NaOH}$ $10 \%$. Hasil positif ditunjukkan dengan terbentuknya warna merah dari filtrat.

\section{Ekstraksi Dan Persiapan Larutan Uji}

Sebanyak $25 \mathrm{~g}$ serbuk rimpang cabang temulawak diekstraksi dengan 250 $\mathrm{ml}$ etanol $96 \%$ dengan menggunakan peralatan soklet selama 8 jam, pelarut dihilangkan dengan rotary evaporator. Residu di timbang dan ditentukan \% randemennya. Dengan cara yang sama dapat dihitung rendemen ekstrak yang menggunakan metode ekstraksi maserasi dan refluk.

Ekstrak yang diperoleh dengan metode sokletasi dibuat larutan induk dengan konsentrasi 2000 ppm dengan melarutkan $20 \mathrm{mg}$ ekstrak kering dalam air laut sampai menjadi volume $10 \mathrm{ml}$. Selanjutnya dari larutan induk dibuat larutan uji dengan konsentrasi 100, 50, 25, 10 dan 5 ppm dalam $10 \mathrm{ml}$ air laut. Ekstrak yang sukar atau tidak larut dibantu dengan penambahan 1 tetes tween- 80 sebelum ekstrak diencerkan.

\section{Uji Toksisitas Terhadap Larva Udang}

Telur Artemia salina L. ditetaskan dalam gelas piala ukuran 1 liter yang diisi dengan air laut yang telah disaring. Penetasan dibantu dengan pemberian aerasi dan cahaya lampu TL agar menetas sempurna, setelah satu hari telur udang akan menetas menjadi larva.Setelah 48 jam, sebanyak 10 ekor larva udang $(1 \mathrm{ml})$ dimasukkan ke dalam vial uji kemudian ditambahkan larutan ekstrak sehingga konsentrasi akhir dalam vial adalah 5,10, 25, $50 \mathrm{ppm}$. Setiap konsentrasi dilakukan $3 \mathrm{x}$ ulangan, kontrol dilakukan tanpa penambahan larutan ekstrak. Setelah 24 jam, larva udang yang mati di hitung. Data yang diperoleh dianalisis menggunakan Probit Analisis Method untuk menentukan $\mathrm{Lc}_{50}$ dengan selang kepercayaan $95 \%$. Senyawa dengan nilai $\mathrm{Lc}_{50}<1000$ ppm dikatakan memiliki potensi bioaktivitas.

\section{Kromatografi Lapis Tipis}

Pemilihan larutan pengembang untuk memperoleh pemisahan komponen yang baik dan mengetahui jumlah komponen pada ekstrak teraktif dilakukan dengan cara KLT. Sebanyak $5 \mu \mathrm{l}$ ekstrak etanol 96\% menggunakan metode maserasi ditotolkan ditempat-tempat tertentu pada plat yang telah disediakan kemudian keringkan. Plat lalu dielusi dalam bejana yang berisi cairan pengelusi. Eluen yang digunakan adalah toluen : etil asetat $(3: 1)$ dan 3 tetes asam format. Setelah cairan pengelusi mencapai tinggi tertentu pada plat, plat diangkat kemudian dikeringkan pada suhu ruangan. Hasil KLT diamati dengan menggunakan lampu UV dengan panjang gelombang $254 \mathrm{~nm}$ dan $366 \mathrm{~nm}$ kemudian dihitung Nilai Rf dari masingmasing noda.

\section{HASIL DAN PEMBAHASAN Karakterisasi Simplisia}

Sebelum proses ekstraksi, simplisia yang akan diekstrak terlebih dahulu dilakukan karakterisasi terlebih dahulu. Karakterisasi simplisia dilakukan dengan menetapkan kadar air dan kadar abu simplisia. Hasil karakterisasi simplisia rimpang cabang temulawak (Curcuma xanthorriza Roxb.) disajikan dalam Tabel 1.

Tabel 1. Hasil Penetapan Kadar Air dan Kadar Abu Serbuk Simplisia Rimpang Cabang Curcuma xanthorriza Roxb.

\begin{tabular}{|l|c|c|}
\hline Simplisia & $\begin{array}{c}\text { Kadar air } \\
(\mathbf{\%})\end{array}$ & $\begin{array}{c}\text { Kadar } \\
\text { abu }(\boldsymbol{\%})\end{array}$ \\
\hline $\begin{array}{l}\text { Rimpang cabang } \\
\text { Rurcuma xanthorriza } \\
\text { Roxb }\end{array}$ & 7,44 & 8,82 \\
\hline
\end{tabular}

Tabel 1 menunjukkan bahwa simplisia yang digunakan memenuhi kriteria persyaratan sebagai simplisia yang baik (Depkes RI, 1979)

\section{Hasil Penapisan Fitokimia}

Pemeriksaan senyawa metabolit sekunder pada serbuk rimpang cabang temulawak dilakukan dengan pengujian 
terhadap senyawa alkaloid, flavanoid, saponin, kuinon, tannin, dan steroid/triterpenoid. Hasil penapisan fitokimia rimpang cabang temulawak disajikan dalam Tabel 2.

Tabel 2. Hasil Penapisan Fitokimia Rimpang Cabang Temulawak

\begin{tabular}{|l|c|c|c|}
\hline $\begin{array}{l}\text { Golongan } \\
\text { senyawa }\end{array}$ & Standar & Hasil analisis & $\begin{array}{c}\text { Kesim } \\
\text { pulan }\end{array}$ \\
\hline Alkaloid & $\begin{array}{c}\text { Endapan } \\
\text { putih }\end{array}$ & Endapan & + \\
\hline Steroid & $\begin{array}{c}\text { Warna } \\
\text { hijau/biru }\end{array}$ & Warna hijau & + \\
\hline Triterpenoid & $\begin{array}{c}\text { Warna } \\
\text { merah/ungu }\end{array}$ & Warna merah & +++ \\
\hline Flavanoid & $\begin{array}{c}\text { Merah } \\
\text { kekuningan }\end{array}$ & kuning & ++ \\
\hline Tanin & $\begin{array}{c}\text { Biru } \\
\text { kehitaman }\end{array}$ & $\begin{array}{c}\text { Tidak } \\
\text { berubah } \\
\text { warna }\end{array}$ & - \\
\hline Saponin & Busa stabil & $\begin{array}{c}\text { Busa tidak } \\
\text { stabil }\end{array}$ & - \\
\hline Kuinon & Warna merah & Warna merah & +++ \\
\hline
\end{tabular}

\section{Hasil Ekstrasi}

Hasil ekstraksi diketahui bahwa metode maserasi menghasilkan nilai rendemen yang paling rendah dibandingkan dengan metode refluks dan soxhlet yaitu 7,91\% (Tabel 3). Hasil yang paling baik ditunjukan oleh nilai rendemen ekstrak dengan metode soxhletasi yaitu $11,52 \%$. Besarnya rendemen yang dihasilkan oleh soxhletasi dibandingkan maserasi dan refluks antara lain disebabkan karena serbuk simplisia disari oleh cairan pelarut yang murni, sehingga dapat menyari zat aktif lebih banyak karena adanya daur ulang pelarut yang digunakan untuk mengekstrak sampel pada soxhletasi. Daur ulang pelarut dihasilkan melalui proses sirkulasi yang terjadi secara otomatis setiap jamnya. Proses sirkulasi pada waktu ekstraksi menyebabkan senyawa yang terdapat di dalam sampel dapat terekstrak kembali secara maksimum sebab kejenuhan pelarut dapat dicegah karena pelarut yang jenuh akan mengurangi kelarutan senyawa-senyawa ke dalam pelarut sehingga rendemen yang dihasilkan akan berkurang.

Hal lain yang menyebabkan tingginya rendemen hasil soxhletasi dibandingkan maserasi dan refluks adalah cairan pelarut yang diperlukan lebih sedikit dan secara langsung diperoleh hasil yang lebih pekat. Keadaan tersebut berbeda dengan yang terjadi pada ekstrak hasil maserasi, yaitu karena tidak terjadi sirkulasi secara otomatis setiap jamnya sehingga tidak ada penggantian pelarut, hal ini menyebabkan pelarut lama-kelamaan akan jenuh sehingga kemampuan melarutkan senyawa dalam sampel akan berkurang akibatnya rendemen yang dihasilkan sedikit dibandingkan soxhlet dan refluks. Rendemen ekstrak yang dihasilkan pada refluks tidak terlalu banyak seperti pada soxhlet hal ini karena metode ini tidak sesuai untuk senyawa yang termolabil seperti minyak atsiri, karena terjadinya pemanasan yang terus-menerus.

Tabel 3. Rendemen Rimpang Cabang Temulawak Dengan Berbagai Metode Ekstraksi

\begin{tabular}{|c|l|c|c|c|}
\hline No & $\begin{array}{l}\text { Metode } \\
\text { Ekstraksi }\end{array}$ & $\begin{array}{c}\text { Berat } \\
\text { sampel }(\mathrm{g})\end{array}$ & $\begin{array}{c}\text { Berat } \\
\text { residu }(\mathrm{g})\end{array}$ & $\begin{array}{c}\text { Rendemen } \\
(\%)\end{array}$ \\
\hline 1 & Maserasi & 25 & 1.98 & 7.91 \\
\hline 2 & Soxletasi & 25 & 2.88 & 11.52 \\
\hline 3 & Refluks & 25 & 2.40 & 9.60 \\
\hline
\end{tabular}

\section{Hasil Uji Toksisitas Dengan Brine Shrimp Lethality Test (BSLT)}

Hasil ekstraksi berupa ekstrak kental dari tiap pelarut, selanjutnya diuji toksisitasnya terhadap larva udang dengan metode BSLT. Lethal Concentration 50\% $\left(\mathrm{LC}_{50}\right)$ diketahui dengan menghitung jumlah larva udang yang mati karena pengaruh ekstrak. Rekapitulasi nilai $\mathrm{LC}_{50}$ setiap fraksi dapat dilihat pada Tabel 6 . Pada uji pendahuluan dibuat konsentrasi ekstrak 1000, 500, 100 dan 50 ppm. Setiap konsentrasi dilakukan 3 kali pengulangan, untuk kontrol dilakukan tanpa penambahan 
ekstrak tetapi dengan penambahan Tween 80 sebanyak 1 tetes. Setelah 24 jam, larva yang diberi ekstrak refluks masih terdapat larva yang hidup tetapi untuk larva yang diberi ekstrak maserasi dan soklet semua larva mati. Hasil pengamatan pengaruh ekstrak terhadap kematian larva disajikan pada Tabel 4.

Tabel 4. Rata-rata jumlah larva mati dalam BSLT

\begin{tabular}{|c|c|c|c|c|c|}
\hline \multirow{2}{*}{$\begin{array}{c}\text { Metode } \\
\text { ekstraksi }\end{array}$} & \multicolumn{5}{|c|}{ Konsentrasi ekstrak (ppm) } \\
\cline { 2 - 6 } & Kontrol & 50 & 100 & 500 & 1000 \\
\hline Maserasi & 0 & 10 & 10 & 10 & 10 \\
\hline Sokletasi & 0 & 10 & 10 & 10 & 10 \\
\hline Refluk & 0 & 3 & 9 & 9 & 10 \\
\hline
\end{tabular}

Kematian larva tersebut disebabkan konsentrasi ektrak yang terlalu tinggi sehingga konsentrasi ekstrak yang digunakan diturunkan menjadi 50, 25, 10, 5 ppm. Hasil pengamatan pengaruh ekstrak terhadap kematian larva dalam air laut yang mengandung ekstrak etanol maserasi, sokletasi dan refluk masing-masing pada konsentrasi 50, 25, 10, dan 5 ppm disajikan pada Tabel 5.

Tabel 5. Rata-rata jumlah larva mati pada BSLT

\begin{tabular}{|c|c|c|c|c|c|}
\hline Metode & \multicolumn{5}{|c|}{ Konsentrasi ekstrak (ppm) } \\
\cline { 2 - 6 } Ekstraksi & Kontrol & 5 & 10 & 25 & 50 \\
\hline Maserasi & 0 & 0.33 & 3,2 & 8,3 & 10 \\
\hline Sokletasi & 0 & 1 & 3,5 & 6 & 10 \\
\hline Refluk & 0 & 0,33 & 2,1 & 4,3 & 7 \\
\hline
\end{tabular}

Selanjutnya data yang diperoleh dianalisis dengan menggunakan Probit Analisis Method untuk menentukan $\mathrm{LC}_{50}$ dengan selang kepercayaan 95\%. Hasil analisis menggunakan Probit Analisis Method disajikan pada Tabel 6.

Tabel 6. Rata-rata $\mathrm{LC}_{50}$ (ppm) Ekstrak Etanol 96\% Rimpang Cabang Temulawak

\begin{tabular}{|c|l|c|}
\hline No & $\begin{array}{l}\text { Jenis metode } \\
\text { ekstraksi }\end{array}$ & $\begin{array}{c}\mathrm{LC}_{50} \\
(\mathrm{ppm})\end{array}$ \\
\hline 1 & Maserasi & 14.87 \\
\hline 2 & Soxlet & 10.13 \\
\hline 3 & Refluks & 35.92 \\
\hline
\end{tabular}

Meyer (1982) menyebutkan bahwa ekstrak dengan $\mathrm{LC}_{50} \leq 30 \mathrm{ppm}$ tergolong kategori sangat toksik, sedangkan $31 \mathrm{ppm}$ $<\mathrm{LC}_{50} \leq 1000$ ppm tergolong kategori toksik . Berdasarkan statmen Meyer, maka nilai LC $_{50}$ 14,87 ppm (Tabel 6) maka ekstrak etanol 96\% rimpang cabang temulawak dengan menggunakan metode maserasi tergolong kedalam kategori sangat toksik. Sedangkan ekstrak etanol 96\% rimpang cabang temulawak dengan metode refluks dengan nilai $\mathrm{LC}_{50} 35,92$ ppm tergolong ke dalam kategori toksik. Ekstrak etanol $96 \%$ rimpang cabang temulawak dengan menggunakan soxhlet dengan nilai $\mathrm{LC}_{50} 19,13$ ppm sama seperti ekstrak maserasi tergolong ke dalam kategori sangat toksik. Nilai $\mathrm{LC}_{50}$ terkecil dihasilkan oleh ekstrak etanol 96\% maserasi sehingga ekstrak tersebut merupakan ekstrak teraktif yang akan digunakan untuk uji lebih lanjut. Ekstrak ini memiliki kandungan senyawa metabolit sekunder yang lebih banyak dibandingkan ekstrak lainnya.

Dibandingkan dengan ekstrak dengan metode maserasi dan soxhlet, ekstrak dengan metode refluks mempunyai nilai $\mathrm{LC}_{50} \quad 35,92$ dan jika diuraikan berdasarkan $\mathrm{LC}_{50}$, maka diketahui ekstrak refluks rimpang cabang temulawak yang paling tidak aktif (toksisitas rendah) tetapi masih tergolong ke dalam kategori toksik, hal ini disebabkan oleh adanya pemanasan yang terus-menerus pada proses ekstraksi yang menyebabkan senyawa yang terkandung dalam ekstrak tidak semua terbawa karena mungkin ada senyawa yang tidak tahan pemanasan sehingga yang senyawa yang tinggal dalam ekstrak hanya senyawa yang tahan terhadap panas. Begitu pula pada ekstrak soklet, karena proses ekstraksi dengan cara panas sehingga senyawa yang termolabil tidak terbawa. Tetapi untuk ekstrak maserasi, karena metode ini merupakan ekstraksi dengan cara dingin maka hampir semua komponen bioaktif baik yang bersifat polar, semi polar dan non polar terbawa dalam ekstrak. 
Hasil penelitian menunjukkan bahwa suhu pada proses ekstraksi dapat mempengaruhi keaktifan tiap ekstrak terhadap toksisitas larva udang Artemia salina.

\section{Hasil Fitokimia Ekstrak Teraktif}

Penapisan fitokimia bertujuan untuk mengetahui golongan senyawa apa yang terkandung di dalam ekstrak teraktif, ekstrak teraktif adalah ekstrak etanol 96\% dengan metode maserasi. Berdasarkan hasil penapisan fitokimia terhadap serbuk dan ekstrak maserasi menunjukkan bahwa ekstrak positif kuat mengandung senyawa kuinon, positif sedang mengandung senyawa triterpenoid, dan positif lemah mengandung steroid, alkaloid dan flavonoid, tetapi tidak ditemukan adanya saponin dan tannin.

\section{SIMPULAN DAN SARAN Simpulan}

Berdasarkan hasil penelitian menunjukkan bahwa ekstrak etanol 96\% dengan metode maserasi merupakan ekstrak yang mempunyai toksisitas paling kuat dbandingkan dengan ekstrasi dengan

\section{DAFTAR PUSTAKA}

Darwis, S.N., Haiyah, S., Madjo, A.B.D. 1991. Tumbuhan Obat Famili Zingiberaceae. Pusat Penelitian dan Pengembangan Industri. Bogor.

Departemen Kesehatan Republik Indonesia. 1979. Farmakope Indonesia. Edisi III. Departemen Kesehatan RI. Jakarta.

$\begin{array}{lr}\text { Medika Indonesia. } & \text { Milid III } \\ \text { Direktorat Jenderal Pengawasan } \\ \text { Obat dan Makanan. Jakarta } \\ \text { Harborne, J.B. 1996. Metode Fitokimia } \\ \text { Penuntun Cara dan Modern } \\ \text { Menganalisis Tumbuhan. Terbitan } \\ \text { kedua. Institut Teknologi Bandung. } \\ \text { Bandung. }\end{array}$

metode socklet dan refluk. Nilai $\mathrm{LC}_{50}$ untuk ekstrak etanol rimpang cabang temulawak dengan metode maserasi, soklet dan refluks berturut-turut sebagai berikut: 14,87 ppm, 19,13 ppm dan 35,92 ppm.

Hasil penapisan fitokimia dari ekstrak etanol $96 \%$ (maserasi) menunjukkan terdapatnya senyawa golongan alkaloid, flavonoid, steroid, kuinon dan triterpenoid pada ekstrak tersebut.

\section{Saran}

1. Perlu dilakukan penelitian lebih lanjut untuk mengisolasi dan mengidentifikasi komponen bioaktif yang terkandung dalam ekstrak etanol 96\% rimpang cabang temulawak dengan menggunakan Kromatografi Lapis Tipis Preparatif.

2. Masyarakat dapat memanfaatkan rimpang cabang temulawak (Curcuma xanthorriza Roxb.) sebagai obat tradisional seperti rimpang induk temulawak karena telah diketahui mempunyai aktivitas biologis.

Meyer, B.N., Ferrigni, N.R., Putnam, J.E., Jacobsen, L.B., Nicols, D.E. and McLaughlin, J.L. 1982. Brine Shrimp: A Covenent General Bioassay for active Plant constituent.Planta Medica.

Schunack, W.K. Mayer dan M. Haake.1990. Senyawa Obat. Ed.ke2. Terjemahan J.R. Wattimena dan S.Subito. gajah mada Universitas Press., Yogyakarta.

Sidik, M. dan Ahmad, M. 1992. Temulawak. Yayasan Pengembangan Bahan Alami Phyto Medica. Jakarta.

WHO. 1999. WHO Monograph on selected medicinal plants. Vol I. ISBN 92125178. Geneva: WHO.www.psa@ deptan.go.id 
Fitofarmaka, Vol. 1 No.2 , Pebruari 2011: 14-21 